\title{
Parents' beliefs about and associations to their elementary children's home technology usage
}

\section{Taylor Downes ${ }^{1} \cdot$ Dane Marco Di Cesare $^{1} \cdot$ Tiffany L. Gallagher $^{1} \cdot$ Jennifer Rowsell ${ }^{2}$}

Received: 28 January 2020 / Accepted: 8 April 2020 /Published online: 22 April 2020

(C) Springer Science+Business Media, LLC, part of Springer Nature 2020

\begin{abstract}
This study sought to gather information through a survey of how newcomer parents' beliefs about technology usage and how they engage with technology as they support their children with twenty-first century literacies. Parent respondents $(N=70)$ were drawn from two publicly funded schools in the Niagara Region, Ontario, Canada, where the population tends to be immigrant, visible minority, with post-secondary education, but unemployed and low income. Descriptive statistics quantified daily technology activities as being communication-oriented with the majority of parents holding distinct beliefs about the amount and type of their children's technology usage. Chi-square tests indicated significant associations for demographic characteristics such as the gender, age, education, first language, and ethnicity of the parents as determinants of their beliefs about their children's technology usage (e.g., social media, mobile phones, television). As well, levels of access and use varied in terms of the number of new technologies and the types of literacy practices that families engage in. Immigrant parents might hold misconceptions about twenty-first century literacies, therefore there should be an attempt to assist them to provide responsive twenty-first century literacy and technology support for their children.
\end{abstract}

Keywords Second-language learners $\cdot$ Technology $\cdot$ Parents $\cdot$ K-12

\section{Introduction}

In Canada, the growing number of newcomer families underscores the need for effective pedagogical support in an evolving global landscape (Cheng et al. 2009).

Taylor Downes

tdownes@brocku.ca

1 Brock University, St. Catharines, ON, Canada

2 University of Bristol, Bristol, UK 
There exists a new reality of language learning needs based on the influx of newcomer students in Canada using technology for the acquisition of twenty-first century literacy skills. These skills include creativity and innovation, communication, critical thinking and problem solving, and collaboration (National Education Association 2002). Often, educators are challenged to support the parents and families with literacy-rich activities that best address the multimodal learning skills of twenty-first century ELL students. Moreover, a recent survey of newcomer parents in Canada also suggests that they have apprehensions about engaging with the school community and feel disconnected from other parents (Xuemei et al. 2016). To add to these challenges, the digital divide persists along racial and class lines (Machado-Casas et al. 2014). In this article, we not only nuance the catch-all notion of 'twenty-first century learning skills' through glimpses of 40 families' experiences of digital literacies, but also we expose some of the more invisible aspects of digital divides in suburban communities.

Thinking across the literature, Mirazchiyski (2016) reports on a large international corpus of data focusing on grade 8 students'socio-economic status (SES) and their computer and information literacy. It was found that in all countries that there was a correlation between the school's low SES and low computer information literacy; however, this effect did not exist on an individual basis such that high SES students are not advantaged compared to low SES students in the same schools. Still, there is a divide between students in low and high SES homes in the type of device used. These findings signal part of the picture of disparities across communities to 'twenty-first century learning.'

It is important to note that there are connections between home and school that impact digital literacies for students from low socioeconomic backgrounds; in particular, teachers need to be mindful of drawing on the digital literacies that students are using in their out-of-school lives (Henderson and Honan 2008). In keeping with this notion, there are recent examples of family digital literacy programs that enhance the literacy skills of the children and the digital literacy of their parents (e.g., Lee et al. 2018). Noguerón-Liu (2017a, 2017b) examined the digital access, use, and beliefs of immigrant parents whose children had access to devices at school and the parents themselves who engaged in technology support workshops. Parents from similar cultural backgrounds used technology in similar ways and other demographic factors such as SES, employment, education influenced parents' beliefs about device usage and access. Such findings highlight strong connections between what Dolan (2016) calls the cans and cannots when it comes to digital literacy skills. That is, if you have the best devices, strong wifi connections, access to software, and importantly, the metaknowledge about how to engage and leverage these communicational systems, students from higher SES backgrounds have an advantage within formal education (Rowsell et al. 2017). So it is with these more lived realities of disparities and types of twentyfirst century skills that have currency in formal education versus more informal and vernacular ones that we base our definition of twenty-first century learning.

Technology use therefore often coincides with social discussion or instruction, whether it be from parents, teachers, or friends. Davidson (2012) found that through discussion, children's research for a project became a topic of social conversation stemming from the images and videos found. Davidson also discovered that children had to make meaning of the verbal instructions given to them by parents or teachers, and translate those instructions into action using their devices. This process of meaning-making through digital literacies becomes a key aspect of childrens' multimedia use and learning and if parents, especially 
newcomer parents, are not familiar with these interactions, the children may not develop the adept ability to navigate their devices for learning.

With regard to social discussion, Davies' (2011) study examined the relationship between parents and their children's technology use at home; ultimately finding that as children grow into adolescents, parents tend to lose control over their children's technology use. However, children who are exposed to a positive relationship between technology and their parents, are likely to develop higher personal autonomy while monitoring or moderating their uses of technology when not monitored by their parents in adolescence. Those adolescents also make digital choices that would be deemed as acceptable by the parents (Davies 2011). Davies also mentions that parents are often anxious about their children's technology use, especially for social purposes, but tend to see the value of some technology for educational purposes. Livingstone and Helsper (2008) support Davies' statements explaining that "parents seem engaged in a constant battle with their children as they seek to balance the educational and social advantages of media use and the negative effects that some content... might have on children's attitudes, behaviour, or safety" (p. 581). The development of a child's skill-set, information base, and familiarity with technology may stem from the strength of parental interaction, guidance, and mediation.

Within the parent-child relationship and experiences using technology at home, Hamlin and Flessa (2018) highlight several key barriers to parent involvement in their childrens' technology use: costs associated with personal technology devices; culturally diverse families' unfamiliarity with their new environment; rural versus urban access; and retraction of parental participation in higher grade levels. Specifically, Hamlin and Flessa discovered that large urban areas need more multilingual support for culturally diverse parents and stronger parental supports for safety while using technology (while parents monitor their children). In Ontario, Canada, the government proposed a Parents Reaching Out Grant Program to aid in parental participation in the many contexts of their children's lives, including the school community. Recently, $11 \%$ of all province-wide initiatives were focused on developing culturally diverse parents' connections with the school and their children's learning via technology or other communication systems (Hamlin and Flessa 2018).

Diallo (2014) contends that mobile devices and apps are instructional tools that are changing English language learning in homes and pedagogy in classrooms. Furthermore, the Ontario Ministry of Education (2008) outlines instruction that effectively uses information technology as a way of supporting language development and engages families. This project explored how schools partner with a local university to use digital resources as tools to co-create learning with newcomer parents in their community. The school community includes a number of parents who are educated immigrants (non-English first language), of a visible minority, but unemployed and low income. The project began with a purview of the type and usage of home technology. Specifically, the project gathered information on how to engage parents as they support their children with twenty-first century literacies.

\section{Project description and survey methods}

This provincially funded project was enacted in two phases chronologically: (1) a parent survey to understand technology access, use and engagement of the families in this school 
community; (2) a series of face-to-face and virtual workshops that supported newcomer parents to interact with their children through technology in the home. A final question on the survey self-identified prospective participants for the second phase of the project. Participation in the survey was independent of participation in the workshops. The findings related to the parent workshops have been published in a special issue (Gallagher et al. 2019). The research method for the first phase of the study was a survey design (Field 2009). The research questions that guided this study are:

1. What are the home technology usages of parents and their elementary school-aged children?

2. Are there associations among the parents' and their elementary school-aged children's home technology usages?

3. Are there associations among parents' technology usage and their beliefs about their elementary school-aged children's home technology usage?

4. Are there associations among the demographic characteristics of parents and:

a. the types of activities they do with technology?

b. their beliefs about their elementary school-aged children's home technology usages?

\subsection{Instrument and data collection}

The survey (see Appendix A) was designed by the research team and based on the need to capture current, Canadian data on the twenty-first century resources that families are accessing in their homes and parents' beliefs about technology usage. The survey was vetted by education faculty, school administrators, a literacy consultant and elementary teachers. There were nine demographic questions (e.g., gender; ethnicity; first language speak/read/write; number of children) and then questions regarding home technology and usage for the parent and with their child(ren) (e.g., television; computer; tablet; SMART phone; video games; internet connection; email). Finally, some questions asked parent participants about home technology practices such as their daily activities that require technology, and the duration and use of home technology for their child(ren). An electronic link to the GOOGLE survey was disseminated to all parents in two school (K-Grade 8) sites. Consent to participate in the survey was garnered within the introduction and choice to move beyond the first page.

\subsection{Participants}

The survey was administered to parents in two medium-to-large publicly funded schools in the Niagara Region, Ontario, Canada. In this region, $14 \%$ of the population between the ages of 25 and 64 has not completed their high school education; over $27 \%$ of families with children are single-parents; over $10 \%$ of the population has immigrated to the region (Niagara Region 2015). There are $8.8 \%$ of the population that identify as a visible minority and $96.4 \%$ as English First-language spoken (Statistics Canada 2017a, 2017b). The unemployment rate in the Niagara Region is $6.2 \%$ and $12 \%$ of people living in Niagara are considered to be low income (Employment and Social Development Canada 2013). 
The schools that participated in this survey are in the same aggregate dissemination area according to Statistics Canada, 2016 Census of Population (2017). The school student populations were 497 and 409 respectively. For this school community area, $10.5 \%$ of the population between the ages of 25 and 64 has not completed their high school education; $18 \%$ of families with children are single-parents; $21.5 \%$ of the population has immigrated to the community. There are $10 \%$ of the population that identify as a visible minority and $96.9 \%$ as English First-language spoken. The unemployment rate in the school community area is $8.5 \%$ and $15.5 \%$ are considered to be low income.

In sum, when compared to the Niagara Region as a whole, the parent population for this school community was more likely to be an immigrant, identifying as a visible minority and holding a post-secondary education. These parents were less likely to be in a single-parent family dynamic, but more likely to be unemployed and low income.

There were 70 parent/guardian respondents (68\% female; $32 \%$ male; mean age 39 years) each representing a single case or unique family. Based on the total school dissemination, the parent participant response rate was $17.5 \%$. The parent respondents had a mode of 2 children $(\bar{x}=2.26)$ with a minimum to a maximum range of 1 to 5 . The age of the first-born child was tri-modal $(8,9,10$ years old); the age of the second-born child was a mode of 6 years old. Table 1. is a summary of the demographic characteristics of the parent sample (additional demographics are available on request).

\subsection{Data analysis}

Survey responses were culled in a GOOGLE document and then converted into files for analyses in SPSS (2014). It should be noted that for all 48 of the survey questions, there was not less than a $97 \%$ question response rate. The data that were categorical were nominally coded and frequency counts and percentages were calculated. Where scale data existed (e.g., age; number of children), measures of central tendency were calculated. These descriptive statistics are presented in Tables 2, 3, 4, 5 and 6 below.

To answer the research questions that query whether there are associations among demographic characteristics and technology use, the Chi-Square Test of Independence was used within SPSS (Field 2009). This non-parametric test determines whether there is an association between categorical variables, or whether the variables are independent or related. Significance level was set at $p \geq 0.05$ for all of the potential question responses, collapsing into aggregated clusters was done in advance of calculating the Chi-Square Tests of Independence. Aggregated clusters were determined by using the mode as a cut-off point (e.g., a mode of 10 would have a cluster of 1-10 and a second cluster of 11+) (Zambelli 2016). Then the Chi Square analyses were re-calculated.

\section{Results}

To respond to the first research question, "What are the home technology usages of parents and their elementary school aged children?" descriptive statistics were calculated for the questions that related to parents' technology use in the home and the parents' perceptions of their child(ren)'s technology use. Table 3. presents descriptive 
Table 1 Demographic characteristics of parent sample

\begin{tabular}{|c|c|c|}
\hline Demographic Characteristic & Descriptor & Percentage of Sample \\
\hline \multirow[t]{4}{*}{ Ethnicity } & White & $67.1 \%$ \\
\hline & Latino & $14.3 \%$ \\
\hline & Eastern/Black & $7.1 \%$ \\
\hline & Central/Latin America & $5.7 \%$ \\
\hline \multirow[t]{4}{*}{ Country of Birth } & Canada & $55.7 \%$ \\
\hline & Central/Latin America & $17.1 \%$ \\
\hline & Other & $17.1 \%$ \\
\hline & USA/UK & $4.3 \%$ \\
\hline \multirow[t]{3}{*}{ First Language } & English & $58.6 \%$ \\
\hline & Other & $20.0 \%$ \\
\hline & Spanish & $15.7 \%$ \\
\hline \multirow[t]{4}{*}{ Other Languages Spoken } & Monolingual & $54.3 \%$ \\
\hline & English & $22.9 \%$ \\
\hline & Trilingual & $10 \%$ \\
\hline & Other & $7.1 \%$ \\
\hline \multirow[t]{4}{*}{ Marital Status } & Married/Common Law & $74.3 \%$ \\
\hline & Single & $12.9 \%$ \\
\hline & Divorced/Separated & $5.7 \%$ \\
\hline & Widowed & $1.4 \%$ \\
\hline \multirow[t]{4}{*}{ Relation to Child } & Biological & $88.6 \%$ \\
\hline & Step & $2.9 \%$ \\
\hline & Adoptive & $1.4 \%$ \\
\hline & Grandparent & $1.4 \%$ \\
\hline \multirow[t]{4}{*}{ Highest level of Education Completed } & Bachelors & $45.7 \%$ \\
\hline & Some Post Secondary & $28.6 \%$ \\
\hline & High School & $12.9 \%$ \\
\hline & Masters or Doctorate & $7.1 \%$ \\
\hline \multirow[t]{4}{*}{ Employment Status } & Working & $61.4 \%$ \\
\hline & Keeping House/Retired & $15.7 \%$ \\
\hline & Unemployed & $10 \%$ \\
\hline & Student & $7.1 \%$ \\
\hline
\end{tabular}

findings for the parents', children's, and family technology use by device. The mode or dominant response is presented as a percentage of the sample in parentheses.

The following summary, Table 4., presents the parent respondents' daily technology activities and practices in the home. The percentages are a portion of the total sample of respondents.

Parent respondents were asked how much home technology use they believe is appropriate for their child(ren). The majority (45.7\%) responded with "some" and then "limited" (38.6\%) followed by "extensive" (10\%). Table 5. summarizes the parent respondents' beliefs about how their child(ren) should use technology in the home. 
Table 2 Demographic questions pertaining to findings

\begin{tabular}{|c|c|c|}
\hline $\begin{array}{l}\text { Demographic } \\
\text { Questions Pertaining to Findings }\end{array}$ & Original Grouping & $\begin{array}{l}\text { Collapsed Grouping } \\
\text { Based on Mean }\end{array}$ \\
\hline What is your age? & $20-29 ; 30-39 ; 40-49 ; 50-69$ & $20-39$ or $40+$ \\
\hline What is your ethnicity & $\begin{array}{l}\text { Latino/Hispanic; Eastern } \\
\text { /Black; Asian; White }\end{array}$ & $\begin{array}{l}\text { Latino/Hispanic/Eastern } \\
\text { /Black/Asian or White }\end{array}$ \\
\hline What country were you born in? & $\begin{array}{l}\text { Canada; USA; Central } \\
\text { /Latin America; Other }\end{array}$ & $\begin{array}{l}\text { Canada or USA/Central } \\
\text { /Latin America/Other }\end{array}$ \\
\hline What language did you speak first? & English; Spanish; Other & English or Spanish/Other \\
\hline Highest level of school completed? & $\begin{array}{l}\text { High school/GED; } \\
\text { Post-Secondary/No } \\
\text { Degree; Bachelor } \\
\text { Degree; Masters or higher }\end{array}$ & $\begin{array}{l}\text { High school/GED/Post } \\
\text {-Secondary/No degree } \\
\text { or Bachelor Degree/Masters } \\
\text { or higher }\end{array}$ \\
\hline
\end{tabular}

The results of the Chi-Square Tests of Independence answer research questions \#2-\#4. For the second research question, "Are there associations among the parents' and their elementary school aged children's home technology usages?" there was a significant association between parents' number of hours on their phone and their child(ren)'s number of hours on their phone $(\mathrm{s})\left(X^{2}(1)>=4.493, p=0.034\right)$. The majority of the parents spent 1-22 $\mathrm{h}$ on their phones and their child(ren) spent $1-7 \mathrm{~h}$ on their phones.

For the third research question, "Are there associations among parents' technology usage and their beliefs about their elementary school-aged children's home technology usage?" there was a significant association between parents' use of social media in the home and their beliefs about their child(ren)'s amount of home technology use $\left(X^{2}(2)>=6.798, p=0.033\right)$. The majority of the parents were social media users and believed that their child(ren) should have some home technology use.

There were several significant results for the fourth research question, "Are there associations among the demographic characteristics of parents and the types of activities they do with technology and their beliefs about their elementary school-aged children's home technology usages?" This question required an investigation of the demographic characteristics of parents (age, ethnicity, birth country, highest level of education, first language) and their activities with technology. There was a significant association between parents' age and their child(ren)'s number of hours on television $\left(X^{2}(1)>=9.727, p=\right.$ 0.002 ). The majority of the parents who were 20-39 years old had children that spent $1-13 \mathrm{~h} /$ week on television. Similarly, there was a significant association between parents' age and the parents' use of technology for leisure activities $\left(X^{2}(1)>=3.688, p=0.05\right)$. The majority of the parents who were $40+$ years old used technology for leisure time.

There was a significant association between parents' ethnicity (i.e., White; Latino) and the parents' use of technology for leisure activities $\left(X^{2}(1)>=4.696, p=0.03\right)$. The majority of the parents who were White used technology for leisure time; whereas, there were no trends with respect to how parents who were Latino, Black, or Asian used technology for leisure vs. work (e.g., scheduling, directions, information, correspondence). In a related fashion, a significant association existed between parents' birth country (i.e., Canada; Latin America) and the parents' use of 


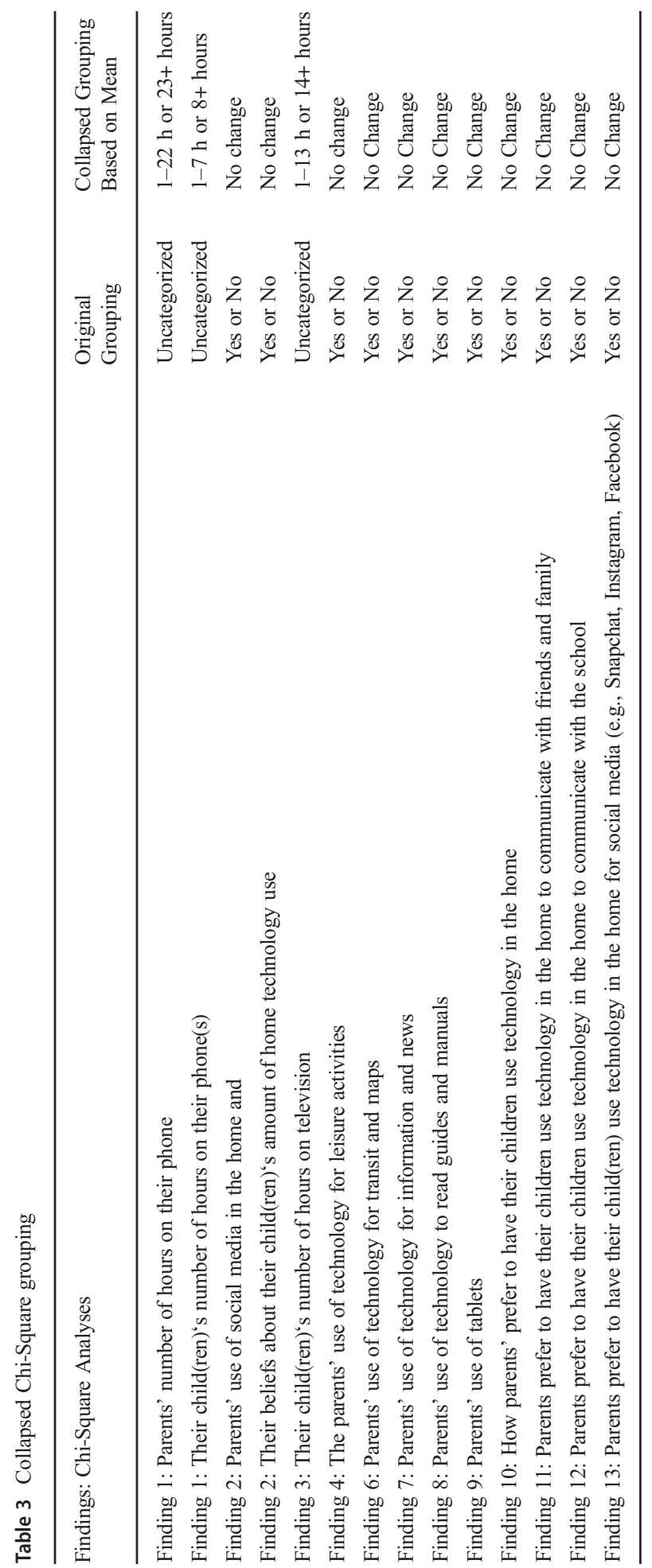




\begin{tabular}{|c|c|c|c|c|}
\hline 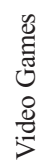 & 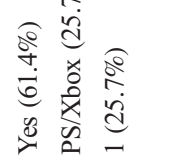 & 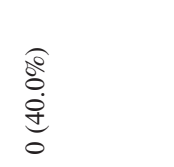 & $\therefore$ & $\underset{\substack{\stackrel{o}{d} \\
\stackrel{0}{0}}}{0}$ \\
\hline 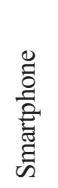 & 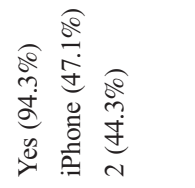 & $\begin{array}{l}\stackrel{0}{\circ} \\
\stackrel{0}{0}\end{array}$ & 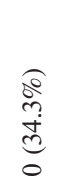 & $\begin{array}{l}\widehat{0} \\
\stackrel{0}{0} \\
0 \\
0\end{array}$ \\
\hline$\frac{\frac{\vec{J}}{\frac{\pi}{\pi}}}{\frac{\pi}{\sqrt{J}}}$ & 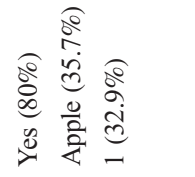 & $\begin{array}{l}\frac{\sigma}{2} \\
\stackrel{0}{0} \\
0\end{array}$ & 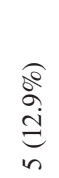 & 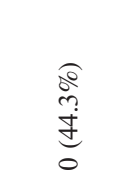 \\
\hline 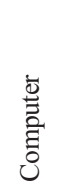 & 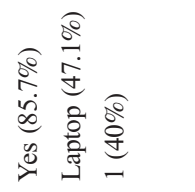 & 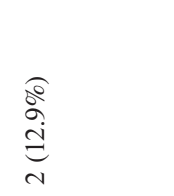 & $\underset{m}{\stackrel{o}{\stackrel{o g}{E}}}$ & 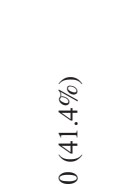 \\
\hline 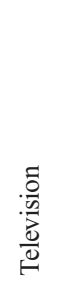 & 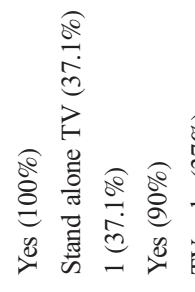 & 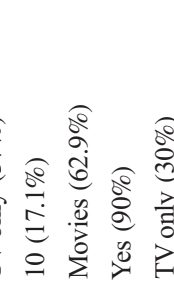 & 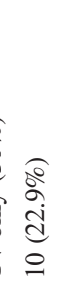 & 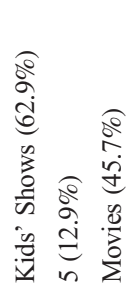 \\
\hline & 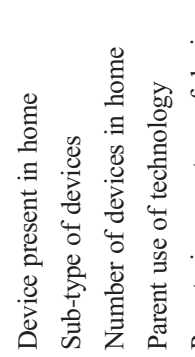 & 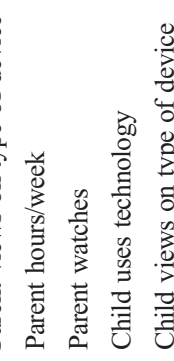 & 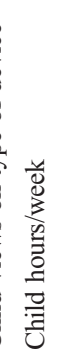 & 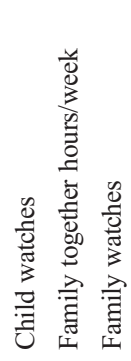 \\
\hline
\end{tabular}


Table 5 Parents' daily activities and practices with technology in the home

\begin{tabular}{lr} 
Email & $94.3 \%$ \\
\hline Internet connection in home & $91.4 \%$ \\
Information Seeking & $85.7 \%$ \\
Correspondence or communication & $82.9 \%$ \\
Texting \& communication & $82.9 \%$ \\
Email communication school & $72.9 \%$ \\
Work or school & $71.4 \%$ \\
Scheduling use & $68.6 \%$ \\
Social media & $68.6 \%$ \\
Information \& news & $67.1 \%$ \\
Transit map use & $58.6 \%$ \\
Leisure use & $54.3 \%$ \\
Scheduling & $47.1 \%$ \\
Watching TV \& videos & $47.1 \%$ \\
How-to-guides & $44.3 \%$ \\
\hline
\end{tabular}

technology for transit and maps $\left(X^{2}(1)>=4.760, p=0.029\right)$. The majority of the parents who were not native to Canada (USA/UK/Central-Latin America) used technology for transit/maps.

As well, there was a significant association between parents' highest level of education (i.e., high school; bachelor's degree) and the parents' use of technology for information and news $\left(X^{2}(1)>=4.001, p=0.045\right)$. The majority of the parents with a post-secondary education degree (i.e., bachelor's or masters' or doctoral) used technology for accessing information and news.

Two significant associations existed between parents' first language that they speak (i.e., English; Spanish) and parents' use of technology to read guides and manuals $\left(X^{2}(2)>=8.661, p=0.013\right)$; the majority of the parents who were English-first speaking used technology while reading guides and manuals. The majority of the parents who were English-first speaking have a tablet in the home, $\left(X^{2}(2)>=9.484, p=0.009\right)$, whereas parents speaking Spanish or other languages tend not to have a tablet in the home.

The next group of three significant associations also relate to parents' first language and connections to their beliefs about their child(ren)s' technology use. There was a significant association between parents' first language that they speak (i.e., English) and how parents' prefer to have their children use technology in the home

Table 6 Parents' beliefs about child(ren)'s use of technology in the home

School (e.g., homework; educational apps) 
$\left(X^{2}(2)>=13.165, p=0.001\right)$ such that the majority of the parents who were English speaking prefer their children to use technology in the home for entertainment (e.g., playing games, watching movies), whereas parents speaking Spanish or other languages tend not to have this preference. Second, there was a significant association between parents' first language that they speak and if parents prefer to have their children use technology in the home to communicate with friends and family $\left(X^{2}(2)>=6.436, p=0.040\right)$; specifically, the majority of the parents who were English speaking prefer their children to use technology in the home for communicating with family and friends, whereas parents speaking Spanish or other languages tend not to have this preference. Third, there was a significant association between parents' first language that they speak and if parents prefer to have their children use technology in the home to communicate with the school $\left(X^{2}(2)>=7.787, p=0.020\right)$; interestingly, the majority of the parents who were English speaking prefer their children not to use technology in the home for communicating with school, whereas parents speaking Spanish or other languages do not have this preference.

The final group of three significant associations relate to parents' gender (specifically female/mother figure) and associations with their beliefs about their child(ren)s' technology use. First, there was a significant association between parents' gender and how parents prefer to have their child(ren) use technology in the home for social media (e.g., Snapchat, Instagram, Facebook) $\left(X^{2}(1)>=10.455, p=0.001\right)$. The majority of the female parents/guardians prefer their children not to use technology in the home for social media. There was a significant association between parents' gender and how parents prefer to have their children use technology in the home to communicate with friends/family $\left(X^{2}(1)>=4.733, p=0.03\right)$. The majority of the female parents/guardians prefer their children to use technology in the home for communicating with family and friends. There was a significant association between parents' gender and how parents prefer to have their child(ren) use technology in the home to communicate with school $\left(X^{2}(1)>=4.179, p=0.041\right)$. The majority of the female parents/guardians prefer their children not to use technology in the home for communicating with school.

\section{Discussion and conclusions}

We have highlighted the results for the newcomer families in order to foreground their needs. As a whole, this project sought to explore ways for parents to engage with their children in contemporary ways for using, communicating and thinking through new technologies. The survey phase of the project, described in this paper, allowed researchers to evaluate access and use of new technologies by parents. For example, this study concluded that $96.7 \%(n=60)$ of parents prefer their children to use technology for school while only $11.7 \%$ of parents want their children using technology for social media; while $73.3 \%$ of those parents use social media at home themselves, but only $53.3 \%$ of them use technology at home for work purposes. These levels of access and use varied in terms of the quantity of new technologies as well as the types of literacy practices that families engage in. There is an important implication to this specific finding because the pedagogical trends in global education are for more converged (Jenkins 2006) and online (or at least hybrid) models of twenty-first century learning skills (Ito et al. 2010) than ever. Reflecting on March 2020, for instance, with 
the ubiquitous use of and leveraging of social media to teach elementary and secondary students during the COVID-19 crisis, understanding the ways that social media works, communicates, and converges films, podcasts, and newsfeeds are essential to do well in school. To achieve in twenty-first century learning implies acumen and competence with curating information online within social media and other genres of digital texts. It also requires capitalizing on online models of collaboration through different digital tools, programs, or applications. The fact that parents discourage social media use where higher SES families might encourage it, signals a key finding about disparate framings of what successful twenty-first century is and looks like.

The research also points to anxieties that parents have about the kinds of technology that their children access and their sharing of private information. Pervasively, parents are also concerned about the amount of time that their children spend on phones, television and social media. Immigrant parents, in particular, might hold misconceptions about digital literacy that other parents do not hold. The study's third research question, although not significant, descriptively explains that more immigrant parents like their children using technology for social media in the home versus Canadian parents (ratio of 5:3). Noguerón-Liu (2017b) found that immigrant adults have varied understandings of online privacy and digital practices that range from being critical consumers and adept users of social media and software to those who have no online experience. Again, this type of finding spotlights a misconception by newcomer families that technologies take away from academic learning when in fact much of it is about critically framing content, digital practices, and curating the right and accurate types of texts to complete academic tasks and create content.

Educators who are interested in enhancing the benefits of using digital resources for their newcomer students should review the ways that technology is used by parents and their children. Exploring parents' understandings and apprehensions about using digital resources to support literacy instruction may provide a niche for effective home-school connection opportunities. The age of the children can also be a mitigating factor. Middle school students (both English first-language and ELL) overall did not report using technology for specific purposes, however, ELL middle school students in grade 6 reported using technology to support their own English skills (Li et al. 2015). Perhaps the type of digital resources needs to be more broadly considered. For example, a recent study of newcomer children found that participating in video gaming communities promoted their socialization, technology use and multimodality (Duran 2017). Moreover, video-game based language instruction has been used by Héctor (2015) to ameliorate the difficulties surrounding English learning needs of newcomer students from different socio-economic backgrounds.

There should be an attempt to assist newcomer parents to provide responsive twenty-first century literacy support for their children. Machado-Casas, Sánchez, and Ek (2014; p. 150) engaged Latina/o immigrant parents in a technology program that encouraged them to use "technology as a bridge for connecting with their children, getting involved with the school, and becoming part of the local and global $21^{\text {st }}$ century community." In another example, Levinson and Barron (2018) documented the positive outcomes of Latina/o immigrant families' supported use of digital resources (i.e., tablets) to help themselves as parents along with their children learn literacy related content and English. These researchers point to the implementation limitations that include finding appropriate app resources and the cost of technology to newcomer families. 
Newcomer parents need to be drawn into a safe communal space that is supportive, educational and enhances their culturally relevant communication (Xuemei et al. 2016). They need to recognize ways that they can use their cultural backgrounds as funds of knowledge (González et al. 2005) for academic, school work. A promising example is found with Lee et al. (2018) who facilitated a program supplying refurbished laptops, literacy and technology resources (including bilingual and culturally relevant children's books) and parent workshops for the immigrant parents of elementary children. It was found that the technology supported parents' and their children to co-construct literacy learning and agency at home. Noguerón-Liu (2017a) also found that it is critical for the school to provide families with devices and training. Such training should include the benefits of utilizing technology to support twenty-first century skills, with a greater focus on content creation, problem solving tasks, and creativity and innovation. Yet, ultimately, parents still hold distinct beliefs about their role as parents and their children's ethical and appropriate technology use. As parental beliefs and choices dictate the technological actions of the child, it is imperative that better supports for this interaction are required. There is an ongoing need for family digital literacy programs and support for digital equity in newcomer communities to ultimately allow for a stronger partnership between newcomer parents, children, and school systems.

Funding information This research was funded by the Ontario Ministry of Education PRO Grant \#30041812 (2017-2018).

\section{Appendix}

\section{DEMOGRAPHIC QUESTIONS}

How old are you?

What is your biological sex?

What is your gender?

What is your ethnicity?

What is your sexual identity?

What is your first language?

What other languages do you speak?

What languages can you read fluently?

What languages can you write fluently?

\section{HOME TECHNOLOGY \& USAGE QUESTIONS}

Do you have a television in your home?

- Yes

- No

IF IDENTIFIED HAVING A TELEVISION AT HOME

How many televisions do you have at home?

Do you watch television at home? 
- Yes

- No

\section{IF IDENTIFIED WATCHING TELEVISION AT HOME}

What do you use to watch television at home?

- Television

- Computer or Laptop

- Tablet

- Smartphone or cell phone/mobile

- Video Game System or Console

How many hours do YOU spend watching television per week?

How many hours does YOUR CHILD/CHILDREN spend watching television per week?

How many hours do YOU spend watching television with your child per week? Do you have a computer or laptop in your home?

- Yes

- No

\section{IF IDENTIFIED HAVING A COMPUTER IN THE HOME}

What type of computer technology do you have in the home? (select all that apply)

- Desktop personal computer

- Laptop

- Chromebook

- Other (please specify)

How many computers do you have at home?

How many hours do YOU spend using a computer per week?

How many hours does YOUR CHILD/CHILDREN spend using a computer per week?

How many hours do YOU spend using a computer WITH YOUR CHILD/ CHILDREN per week?

Do you have a tablet in your home?

- Yes

- No

IF IDENTIFIED HAVING A TABLET IN THE HOME

What type of tablet do you have in the home? (select all that apply)

- iPad

- Android Tablet

- Kindle 
- $\quad$ Other (please specify)

How many tablets do you have in the home?

How many hours do YOU spend using a tablet per week?

How many hours does YOUR CHILD/CHILDREN spend using a tablet per week?

How many hours do YOU spend using a tablet WITH YOUR CHILD/ CHILDREN per week?

Do you have a smartphone or cell phone/mobile in your home?

- Yes

- No

IF IDENTIFIED HAVING A SMARTPHONE IN THE HOME

What type of smartphone do you have in the home? (select all that apply)

- iPhone

- Android

- Windows Phone

- Amazon Fire Phone

- Other (please specify)

How many smartphones do you have in the home?

How many hours do YOU spend using a smartphone per week?

How many hours does YOUR CHILD spend using a smartphone per week?

How many hours do YOU spend using a tablet with your child per week?

Do you have a video game system or game console in your home?

- Yes

- No

IF IDENTIFIED HAVING A VIDEO GAME SYSTEM OR GAME CONSOLE IN THE HOME

What type of video game system do you have in the home? (select all that apply)

- Nintendo Console (e.g. Wii, WiiU, Nintendo Switch)

- Nintendo Handheld System (e.g. Nintendo DS, Nintendo 2DS, Nintendo 3DS)

- Playstation Console (e.g. PS2, PS3, PS4)

- Playstation Handheld System (e.g. PS Vita, PS Vita 2)

- Xbox Console (e.g. XBox, XBox 360, XBox Kinect, XBox 1)

- Other (please specify)

How many video game systems do you have in the home?

How many hours do YOU spend playing video games per week?

How many hours does YOUR CHILD/CHILDREN spend playing video games per week? 
How many hours do YOU spend playing video games WITH YOUR CHILD/ CHILDREN per week?

Do you have an internet connection in your home?

- Yes

- No

IF IDENTIFIED HAVING AN INTERNET CONNECTION IN THE HOME What type of internet connection do you have at home? (select all that apply)

- Cable

- DSL - through phone company

- Fibre

- Fixed-Wireless

- Dial-Up

Do you use email?

- Yes

- No

IF IDENTIFIED USING EMAIL

(If YES) - Do you use email to communicate with your child's school?

- Yes

- No

\section{HOME TECHNOLOGY PRACTICES QUESTIONS}

What kinds of your daily activities or practices require technology? (select all that apply)

- transit/maps

- scheduling

- leisure

- correspondence/communication

- information seeking

- directions

- $\quad$ other (please specify)

How much home technology use do you feel your child/children should have?

- limited use

- some use

- extensive use

How do you like your children to use technology at home? (select all that apply) 
- for school (e.g. homework, educational apps)

- for life (e.g. play games, social media)

- to communicate with family and friends

- to communicate with school

\section{When do YOU most use technology (in the home)?}

- $\quad$ social media (e.g., Facebook, Instagram)

- texting and communication

- watching television or videos

- information and news

- scheduling

- for work

- for school

\section{References}

Cheng, L., Klinger, D., \& Zheng, Y. (2009). Examining students' after-school literacy activities and their literacy performance on the Ontario secondary school literacy test. Canadian Journal of Education, 32(1), $116-148$.

Davidson, C. (2012). Seeking the green basilisk lizard: Acquiring digital literacy practices in the home. Journal of Early Childhood Literacy, 12(1), 24-45. https://doi.org/10.1177/1468798411416788.

Davies, C. (2011). Digitally strategic: How young people respond to parental views about the use of technology for learning in the home. Journal of Computer Assisted Learning, 27(4), 324-335. https://doi.org/10.1111/j.1365-2729.2011.00427.x.

Diallo, A. (2014). The use of technology to enhance the learning experience of ESL students. (Master's dissertation). Available from ERIC database. (ERIC no. ED545461).

Dolan, J. E. (2016). Splicing the divide: A review of research on the evolving digital divide among K-12 students. Journal of Research on Technology in Education, 48(1), 16-37.

Duran, C. S. (2017). "You not die yet": Karenni refugee children's language socialization in a video gaming community. Linguistics and Education, 421-429. https://doi.org/10.1016/j.linged.2017.09.002.

Employment and Social Development Canada. (2013). EI economic Region of St. Catharines - Niagara. Unemployment Rate. Retrieved from: http://srv129.services.gc.ca/ei regions/eng/stcath.aspx?rates=1.

Field, A. (2009). Discovering statistics using SPSS (3rd ed.). London: Sage Publications.

Gallagher, T. L., Di Cesare, D., \& Rowsell, J. (2019). Stories of digital lives and digital divides: Newcomer families and their thoughts on digital literacy. The Reading Teacher, 72(6), 774-778.

González, N., Moll, L., \& Amanti, C. (2005). Funds of knowledge: Theorizing practices in households, communities and classrooms. Mahwah: Erlbaum.

Hamlin, D., \& Flessa, J. (2018). Parental involvement initiatives: An analysis. Educational Policy, 32(5), 697727.

Héctor, A. G. (2015). Laying the foundations for video-game based language instruction for the teaching of EFL. HOW, 22(1), 107-122.

Henderson, R., \& Honan, E. (2008). Digital literacies in two low socioeconomic classrooms: Snapshots of practice. English Teaching: Practice and Critique, 7(2), 8-98.

Ito, M., Baumer, S., Bittanti, M., Boyd, D., Cody, R., Herr-Stephenson, B., ... Tripp, L. (2010). Hanging out, messing around, and geeking out. Cambridge: The MIT Press.

Jenkins, H. (2006). Convergence culture: Where old and new media collide. New York: New York University Press.

Lee, V. J., Hoekje, B., \& Levine, B. (2018). Introducing technology to immigrant families to support early literacy development and two-generation learning. Language Arts, 95(3), 133-148.

Levinson, A. M., \& Barron, B. (2018). Latino immigrant families learning with digital media across settings and generations. Digital Education Review, 33, 150. 
Li, J., Snow, C., Jiang, J., \& Edwards, N. (2015). Technology use and self-perceptions of English language skills among urban adolescents. Computer Assisted Language Learning, 28(5), 450-478.

Livingstone, S., \& Helsper, E. J. (2008). Parental mediation of children's internet use. Journal of Broadcasting \& Electronic Media, 52, 581-599.

Machado-Casas, M., Sánchez, P., \& Ek, L. D. (2014). The digital literacy practices of Latina/o immigrant parents in an after-school technology partnership. Multicultural Education, 21(3), 28-33.

Mirazchiyski, P. (2016). The digital divide: The role of socioeconomic status across countries. Solsko Polje, 27(3/4), 23-52.

National Education Association. (2002). An educator's guide to the "Four Cs." Retrieved from http://www. nea.org/assets/docs/A-Guide-to-Four-Cs.pdf

Niagara Region. (2015). Health statistics. Retrieved from http://www.niagararegion. ca/health/statistics/demographics/default.aspx.

Noguerón-Liu, S. (2017a). Expanding notions of digital access: Parents' negotiation of school-based technology initiatives in new immigrant communities. Equity \& Excellence in Education, 50(4), 387-399. https://doi.org/10.1080/10665684.2017.1395301.

Noguerón-Liu, S. (2017b). "everybody knows your business"/"Todo mundo se da cuenta": Immigrant adults' construction of privacy, risk, and vulnerability in online platforms. Journal of Adolescent and Adult Literacy, 60(5), 505-513.

Ontario Ministry of Education. (2008). Supporting English language learners: A practical guide for Ontario educators - Grades 1-8. Toronto, ON.

Rowsell, J., Morrell, E., \& Alvermann, D. (2017). Confronting the digital divide: Debunking brave New World discourses. The Reading Teacher, 71(2), 157-165.

SPSS 22 Software. (2014). PASW statistics 22. Chicago: SPSS Inc..

Statistics Canada. (2017a). 35260003 [Aggregate dissemination area], Ontario and Ontario [Province] (table). Census Profile. 2016 Census. Statistics Canada Catalogue no. 98-316-X2016001. Ottawa. Released November 29, 2017. https://www12.statcan.gc.ca/census-recensement/2016/dp-pd/prof/details/page. cfm? Lang $=$ E $\&$ Geo $1=$ ADA $\&$ Code $1=35260003 \&$ Geo $2=$ PR $\&$ Code $2=35 \&$ Search Text $=$ L 2 M 3 X2 $\&$ SearchType $=$ Begins $\&$ SearchPR $=01 \& \mathrm{~B} 1=\mathrm{All} \& \mathrm{TABID}=2 \&$ type $=0$

Statistics Canada. (2017b). Niagara, Regional municipality [Census division], Ontario and Ontario [Province] (table). Census Profile. 2016 Census. Statistics Canada Catalogue no. 98-316-X2016001. Ottawa. Released November 29, 2017. https://www12.statcan.gc.ca/census-recensement/2016/dp$\mathrm{pd} /$ prof/details/page.cfm?Lang=E\&Geo1=CD\&Code $1=3526 \&$ Geo2=PR $\&$ Code $2=35 \&$ SearchText $=$ Niagara $\&$ SearchType $=$ Begins $\&$ SearchPR $=01 \& B 1=A 11 \&$ GeoLevel $=$ PR $\&$ GeoCode $=3526 \&$ TABID $=1$ \&type $=0$

Xuemei, L., Doyle, A., Lymburner, M., \& Ghadi, N. Y. (2016). Parental support for newcomer children's education in a smaller Centre. Comparative and International Education, 45(3), 1-15.

Zambelli, A. (2016). A data-driven approach to estimating the number of clusters in hierarchical clustering. Retrieved from https://arxiv.org/pdf/1608.04700.pdf.

Publisher's note Springer Nature remains neutral with regard to jurisdictional claims in published maps and institutional affiliations. 